Boletim IG. Instituto de Geociências, USP, V. 4:71-85, 1973

\title{
STRATIGRAPHY OF THE IGUAPE-CANANEIA LAGOONAL REGION SEDIMENTARY DEPOSITS, SĀO PAULO STATE - BRAZIL PART II: HEAVY MINERALS STUDIES, MICROORGANISMS INVENTORIES AND STRATIGRAPHICAL INTERPRETATIONS
}

\author{
By \\ Setembrino Petri and Kenitiro Suguio \\ Departamento de Paleontologia e Estratigrafia
}

\section{RESUMO}

Este trabalho versa sobre os estudos de minerais pesados e microorganismos contidos nos sedimentos da região lagunar Iguape-Cananéia.

Os microorganismos, estudados nas amostras de subsuperfície, em confronto com os resultados de amostras de superfície em diferentes ambientes atuais, permitiram um estudo paleoecológico, que foi de valor imprescindível na reconstrução da história geơlógica.

Os exames de minerais pesados foram de grande valia no fornecimento de indicações para a compreensão do problema da derivação dos sedimentos, principalmente em relação às areias regressivas, tipo blanket sands (KRUMBEIN e SLOSS, 1963, p. 550).

As pesquisas realizadas permitiram reconhecer a presença de quatro unidades de sedimentação, bem distintas, registrando a história dos eventos geológicos na área.

A Formação Pariquera-Açu, depósito aluvial distribuído na bacia hidrográfica do Ribeira de Iguape, de modo particular ao longo do rio Jacupiranga (FRANZINELLI, 1970), foi aqui reconhecida tratar-se de um resultado direto dos eventos quaternários ocorridos na região lagunar Iguape-Cananéia.

\section{SUMMARY}

This paper deals, with the studies of the heavy minerals and microorganisms contained in the sediments of the Iguape-Cananéia lagoonal region.

The microorganisms from the subsurface samples and from the present different environments were compared. As a result an inestimable tool was acquired for the reconstruction of the areal sedimentation history.

The heavy minerals gave indications about the source rocks of the sediments, mostly concerning to the regressive sands, blanket sands type deposits (KRUMBEIN and SLOSS, 1963 , p. 550).

The presence of well distinctive four sedimentation unities were recognized as a record of the geological events in the area.

The Pariquera-Açu Formation, old alluvial deposits spreaded in the Ribeira de Iguape hydrographic basin, particularly along the course of the Jacupiranga River (as indicated in the map of FRANZINELLI, 1970), was here recognized as a direct consequence of the quaternary events, occurred downstream, in the IguapeCananéia lagoonal region. 


\section{INTRODUCTION}

The general geological aspects of the area were discussed in the part I of this work (SUGUIO and PETRI, 1973).

Here we present the list of the samples collected by us during the field surveys, with a detailed descriptions about their provenances. The mechanical analysis, previously described, was made in part of these samples. The heavy minerals was studied only in the samples from this list, and the microorganisms inventories was supplemented by the subsurface samples from the I.G.G. wells.

As conclusion we have a outline of the sedimentary history in the studied area.

\section{SAMPLING}

We collected 51 samples from the IguapeCananéia lagoonal region, whose locations were showed in the figura 1 of the part I of this work, Most of them come from piçarra banks, other samples come from the bottom of the Cananéia and Pequeno seas, recent beaches and dunes and river channels. The semples underwent mechanical analysis, heavy minerals counting and Foraminifera and Algae inventories.

TABLE ।

LIST OF THE SAMPLES COLLECTED IN THE IGUAPE-CANANÉIA LAGOONAL REGION (See also fig. 1)

Sample 1 - Subaúma Bay (low tide)

Sample 2 - Road Iguape-Pariquera Açu

Sample 3 - Pequeno sea off Grande Island

Sample 4 - Pequeno sea - Subaúma Bay

Sample 5 - Pequeno sea, between Rodrigues and Comprida Islands

Sample 6 - Cananéia sea, between Garça and Comprida Islands

Sample 7 - Cananéia sea, between Pai Mato and Comprida Islands

Sample 8 - Piçarra at Cananéia town (Read remark)

Piçarra - Local name of the regressive sand's cliffs sediments, cemented by hidrous ferric oxide very rich in humic acid.
Sample 9 - Piçarra on the continent, near the ferry boat pier to Cananéia.

Sample 10 - Piçarra at Rocio (in front of the town of Iguape)

Sample 11 - Comprida Island beach

Sample 12 - Comprida Island dune

Sample 13 - Comprida Island beach (31 $\mathrm{km}$ south from Nossa Sra. do Carmo Hotel)

Sample 14 - Cananéia sea off Beltrami headland

Sample 15 - Cananéia sea off Mangal Comprido headland

Sample 16 - Cananéia sea off Vamiranga

Sample 17 - Pequeno sea off Ponta Grossa

Sample 18 - Pequeno sea off Pedra Balisa

Sample 19 - Pequeno sea between Grande Island and Iguape (narrowest point)

Sample 20 - Pequeno sea off Sanombi Port, in front of the town of Iguape

Sample 21 - Cananéia sea in front of São João Hill

Sample 22 - Cananéia sea outlet in front of the southwestern end of the Comprida Island.

Sample 23 - Piçarra from Acaraú, Cananéia Island, $1.7 \mathrm{~km}$ from the town of Cananéia to SW

Sample 24 - Piçarra left side of the road Cananéia-Ferry boat pier, 2.5 $\mathrm{km}$ from the town of Cananéia.

Sample 25 - idem (as above)

Sample 26 - Mangrove at the ferry-boat pier to Cananéia (at the continent side)

Sample 27 - Piçarra, headwaters of the Votupoca River (Folha Larga Farm)

Sample 28 - Sandy soil, at the road Cananéia to Pariquera-Açu, near the place where sample 27 was collected

Sample 29 - Piçarra, Iririaia-Açu River margin

Sample 30 - Piçarra, near Iririaia-Açu River, about $200 \mathrm{~m}$ from the 


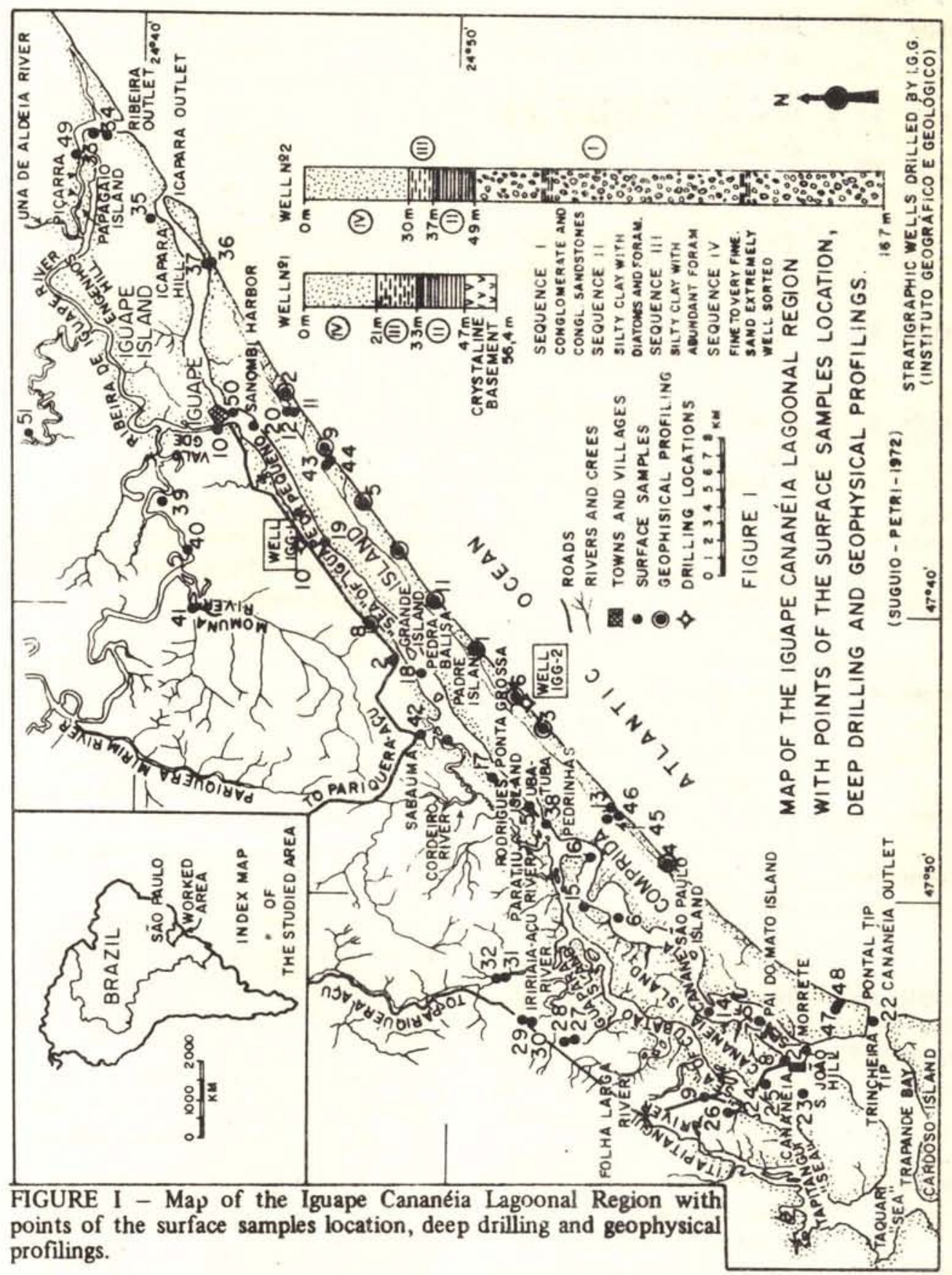

road Cananẻia-Pariquera Açu ( $\mathrm{km}$ 235)

Sample 31 - Picarra. Aroeira road. $200 \mathrm{~m}$ from the bridge

Sample 32 - Sand coarser than the piçurra, $300 \mathrm{~m}$ Irom the place of the sample 31
Sample 33 - Sediment from the Ribeira River, right margin at the Icapara road (near Ribeira's mouth)

Sample 34 -- Piçarra, Icapara road, $1 \mathrm{~km}$ from the Ribeira River

Sample 35 - Piçarra from Icapara outlet (with cross bedding). 
Sample 36 - Beach sands, Comprida Island at its narrowest point, where the dunes cover all its width

Sample 37 - Dune sands, same place of the sample 36

Sample 38 - Piçarra, Comprida Island, bank at the margin of the Pequeno sea between Pedrinhas and Ubatuba (with cross bedding)

Sample 39 - Piçarra, bank of the right margin of the Ribeira River, above Valo Grande

Sample 40 - Piçarra from Barranco Alto (right margin of the Ribeira River up from the place of the sample 39)

Sample 41 - Piçarra, near the margin of the Momuna River

Sample 42 - Piçarra, Subaúma, bank $6.5 \mathrm{~m}$ high at the margin of the Pequeno sea

Sample 43 - Dune sands, $4.7 \mathrm{~km}$ from the beach located at the other side of Sanombi Port, Comprida Island

Sample 44 - Beach sands from the same place of sample 43

Sample 45 - Dune sands, $2.9 \mathrm{~km}$ from the beach located at the other side of Sanombi Port, Comprida Island

Sample 46 - Beach sands from the same place of 45

Sample 47 - Beach sands, $51.1 \mathrm{~km}$ south from the beach located at the other side of Sanombi Port, Comprida Island

Sample 48 - Beach sands coarser than the sands from sample 47 , located at the same place

Sample 49 - Piçarra from the left margin of the Ribeira River, in front of the Papagaio Island

Sample 50 - Sample from a small island in the Pequeno sea, in front of the town of Iguape, in process of formation

Sample 51 - Piçarra, $11 \mathrm{~km}$ from the ferryboat pier of the Ribeira River, at the right side of the Road Iguape-Biguá

\section{HEAVY MINERALS}

The heavy minerals of 26 samples from outcrops were analysed. The samples came from sediments deposited in different environments, such as channels and banks of Ribeira River and its tributaries, piçarras outcropping on the continent, sands from recent beaches and dunes, all belonging to the sequences IV or V. The sequence IV, as explained in the Part I of this work, is made up of regressive blanket sands and the sequence $V$, is made up of sediments from the different environments now occurring in the area (beach, river, dune and lagoon bottom). The sands of the sequence IV have a great lateral persistence so the sediments of the sequence $\mathrm{V}$ are made up of reworked sands from the sequence IV, from variable contributions from other sources according to the kind of the environment.

The heavy minerals separated by the bromoform process from the fractions $0.25-0.125$ $\mathrm{mm}$ and $0.125-0.062 \mathrm{~mm}$ were mounted in thin slides and examined in a polarizing microscope.

The different minerals were counted separately in a average total of 65 grains per slide of the $0.25-0.125 \mathrm{~mm}$ interval and 75 grains per slide of the $0.125-0.062 \mathrm{~mm}$ interval. It seems that generally the quantities of heavy minerals in the finer fraction are greater than the quantities in ther coarser fraction. The magnetite had to be beforehand separated by a magnet.

The main heavy minerals in order of abundance are: chlorite, tourmaline, apatite, zircon, sillimanite and rutile. The magnetite may be the predominant mineral among the opaques; it is followed by ilmenite, and present only in some samples, limonite, leucoxene and possibly hematite. This association of heavy minerals is, in a general way, coincident with that one recognized by PETRI and SUGUIO (1969, p. 21) in the metasediments of the Pre- 
cambrian Açungui Group, which possibly are the main sources of the sediments studied here.

The principal characteristics of the six more frequent minerals are:

Chlorite - Greenish to yellow greenish grains, slightly or not pleochroic, some with inclusions; rounding and sphericity low, indistict cleavage; a false uniaxial well centered interference figure sometimes appears.

Tourmaline - Light yellow and bluish grains, generally well rounded and with high sphericity. Some grains, however, have low rounding and sphericity; they are strongly pleochroic and partly with inclusions.

Apatite - Grains with light yellowish colors and low relief, generally well rounded and some with high sphericity.

Zircon - Colorless, not pleochroic, anisotropic and prismatic grains with frequent inclusions, low sphericity and regularly rounded.

Sillimanite - Colorless, not pleochroic, anisotropic grains with parallel extinction and striated along the length of the prisms. The rounding is low but some grains show rounded margins.

Rutile - Well rounded and low sphericity grains, colored deep red keeping the same color with crossed or parallel nicols.

Only the six species described above were counted semi-quantitatively. The table II contains the results of this counting. It was verified that, with two exceptions, the frequency of these minerals is not significantly different in the two fractions examined. Sillimanite seems to be more frequent in the finer fraction and apatite more frequent in the coarser fraction.

The heavy minerals examined above probably came from the Precambrian rocks; these species make up the association of accessory minerals characteristic of the metamorphic rocks of the Açungui Group (gneisses, quartzites, quartz-micaschists and chlorite-schists). Similar relationship between the accessory minerals of the metamorphic rocks constituting the source rocks of the sediments from the
Taubaté Basin, Paraíba Valley, State of São Paulo, Brazil and the heavy minerals from these sediments were pointed out by SUGUIO (1969, p. 100). The different values of rounding of the same mineral species found out in the sediments of the Iguape-Cananéia region could mean the existence of different phases of sediment supply or reworking of previous sediments. The well rounded hard minerals could mean a sequence of sedimentation and reworking preceding to the deposition of the regressive sands (piçarra). When the piçarras and their reworked sediments (beaches, dunes and river sands) were compared temselves, we were not able to detect any significant difference in the degree of rounding, sphericity or frequency of the different minerals.

\section{MICROORGANISMS STUDIES}

The distributions or foraminifers and diatoms found out in the cores of the two I.G.G. wells are shown in the figures 2 and 3 . One can observe in these two figures, an abrupt delimitation of the assemblages $33.30 \mathrm{~m}$ deep in the well $\mathrm{n} .01$ and $36.70 \mathrm{~m}$ deep in the well $\mathrm{n}$. 2 . The lower sequence is characterized by the predominance of diatoms and the upper sequence by the predominance of forams. Only two species of forams are found in the older beds: $\mathrm{Am}$ monia catesbyana and Cribroelphidium poeyanum. There are however eurythermal and euryhaline species.

The diatom assemblages contain typical brackish waters taxa such as Terpsionoe musica and Cyclatella striata, besides forms commonly found in estuaries such as Polymixus coronalis and Triceratium favus. Marine species appear also in these assemblages, for instance Coscinodiscus asteromphalus as well as fresh water species, for instance, Pinularia nobilis. The association of fresh, brackish and salt water species is common or even typical of brackish water environments (PHLEGER, 1954). The diatoms easily transported by currents are specially fitted for these mixtures.

The foraminiferal assemblage of the sequence III of sedimentation is typical marine 
and its absence in sequence II indicates an improper environment, probably caused by brackish conditions. The absence of brackish water arenaceous forams is explained by the studies of the living assemblages from the Cananéia and Pequeno seas. It is worthy noting that Ammonia and Cribroelphidium appear for the first time only at the depth of $36.35 \mathrm{~m}$ in the well $n ! 1$, indicating an unsuitable environment during most of the time of deposition of sequence II, even for these hard species. A fresh water environment for the sediments of sequence II is ruled out inasmuch as the thecamaebas are absent (For explanation on the sedimentary sequences in the region, see the following chapter or the part I of this same work).

The absence of brackish water forams in the sequence II sediments may possibly be explained by turbid waters. The turbidity of the water in a brackish water environment is a critical factor for the forams distribution (MILLER, 1953, p. 41; LOEBLICH and TAPPAN, 1953, p. 44; CLOSS, 1962, p. 73).

The sediments of the sequence II are remarkably rich in diatoms; the samples desintegrated in water and filtered heap up the filter paper with diatoms.

The living diatoms from Cananéia lagoonal area were investigated by the biologists of the University of São Paulo Oćeanographic Institute (TEIXEIRA and KUTNER, 1961). The diatoms also are impressively abundant in certain areas. BESNARD $(1950$, p. 25$)$ stated that there are always a place in every marigot ${ }^{*}$, not fix but moving with the tides, where the phytoplancton are so abundant that the water changes color. These phytoplancton are predominantly made up of diatoms. The salinity would be the main factor responsible for this concentration. The second factor, in order of importance, would be the great amount of organic terrigenous material. It is significant that the sequence II sediments, rich in diatoms, are also rich in superior plant fragments. These

\footnotetext{
- Marigot is used by BESNARD for the creeks which flow in opposite directions according to the tides. KUTNER (1962, p. 44) called them gamboas.
}

plants are much more than in the sediments of the sequence III.

The environment of deposition of the sequence II sediments would be therefore similar to the lagoonal channels where the waters are rather calm with an abundant influx of fluvial waters from rivers and creeks or from the marigots (MAGLIOCCA and KUTNER, 1964 , p. 1-2). The advancing tides would bring some marine diatoms which would mix up with the brackish ones and with the fresh water ones brought by the rivers and creeks. The diatoms are easier to transport than the forams.

We travelled the Cananéia and Pequeno seas in 1969, taking up samples from the bottoms to be examined for checking our ecological inferences on the environment of deposition of the sediments of the sequence II. The geographical positions of the samples wich are the same used for grain size frequency analysis and heavy minerals counting are shown in the table I (See also figure 1 in the Part I of this work).

The sample where the sea influence is the strongest was collected at the Trapandé Bay outlet (sample n. 22). The sea in this place is rough and the bottom detritus is made up of coarse sands. The microorganisms are not common because of the rough environment. There are many broken pelecypod and gastropod shells and fragments of sea urchin spines. The forams belong to the genera Ammonia, Poroeponides, Elphidium and Nonionella. The environment of this sample is not correlated with any of the wells; it is restrict within the broad variables of the studied area.

The sample n? 21 from the bottom of the Cananeia sed in front of the town of Cananéia, therefore near the place of the sample n? 22 , still have a marked influence of the sea, with broken shells and sea urchin spines. Ostracods are common and the forams belong to many genera. The forams assemblage can be defined as Ammonia, Miliolidae, Elphidiidae, Nonionella atlantica. Very few planktonic forams are present. This assemblage can be com- 
pared with that of the sequence III. They are however similar but not identical. Hanzawaia, frequent in the cores didn't show up in the sample n? 21. On the other hand, several arenaceous genera such as Ammobaculites, Ammobaculoides, Reophax and Trochammina present in the sample $n$. 21 were not found in the cores from the wells. The place where sample n? 21 were collected has already salinity slightly lower than the marine waters, the reason why the arenaceous formas are frequent.

The next sample ( $n \cdot 7$ ) collected off Pai Mato Island, came from a place of typical brackish water. The forams are scarce, mostly Elphidiidae and Ammonia, but the diatoms are frequent. Besides the genera also present in the cores, Coscinodiscus (the commonest), Terpsinoe and Triceratium, there are several ones not present in these cores: Navicula, Navifusa, etc..

The forams disappear completely farther into the Cananéia sea off Beltrami Point (sample no 14). The diatoms, on the other hand, are extremely abundant. The amount of carbonized plants is great. A gastropod looking like Cerithia and Cypricididae, Ostracods with spines on the anterior and posterior extremeties are also abundant. This assemblage can be compared with those from sequence II sediments.

The sample n? 6, from a still farther place into the Cananéia sea, off Garça Island, has only diatoms as microorganisms. The diatoms very abundant heap up the filter paper as in the sediments of sequence II. If we do not take into consideration some diatoms genera (Navicula, Navifusa, etc.) not present in the cores, the two kinds of samples (cores and surface samples) will be very similar.

Here also the carbonized plant remains are abundant. Still farther into the Cananéia sea and the Pequeno sea, off Mangal Comprido (sample n? 15), Vamiranga (sample n? 16), Rodrigues Island (sample n? 5) and Ponta

Grossa (sample n! 17), the associations are equal to that of the sample n.96. The influence of the Ribeira River is stronger and stronger from Subaúma to the mouth of Valo Grande and so the water salinities are lower and lower. The sample n? 4, from Subaúma bay has abundant diatoms associated with an arenaceous foram abundant as well, Miliammina fusca. The thecamaebas (Difflugia) appear for the first time but are rare. This assemblage has no counterpart in the wells. The Miliammina are also common in the samples off Pedra Balisa (n? 18) and Grande Island (n! 3), but near the mouth of Valo Grande (samples n! 19 and 20) they are rare and the thecamaebas common.

The interpretation of the environments of deposition of the sediments of the sequences II and III of the wells is therefore corroborated by the study of the distribution of living forms along the Cananéia and Pequeno sea.

The sequence III foraminiferal assemblage is typically marine; the predominant genera being Ammonia - Miliolidae - Hanzawaia Elphidiidae. We can assume, that the sea was shallow, perhaps not over than $20 \mathrm{~m}$, and nearshore, based on the predominance of Ammo nia (WALTON, 1964, p. 236). The number of species of forams and the abundance of the planktonic forms increase as we depart from the shore. The frequency of Ammonia, on the other hand decreases as we depart from the shore. The figures 4 and 5 show the relations of number of forams, planktonic forams and Ammonia in the different cores of the wells. We might assume looking at these figures some fluctuations of the sea. It seems that in the place of the well $\mathrm{n} .1$ the marine transgression was sudden followed by a slower regression partially originated by filling up of detritus. The data from the well n? 2 are scarce, but we might assume here a slower transgression.

\section{DESCRIPTION AND INTERPRETATION OF THE LITHOLOGICAL UNITIES DRILLED BY THE I.G.G. WELLS}

The four sedimentary sequences above the crystaline basement, drilled by I.G.G. wells n. 1 and n. 2, whose microorganisms contents, were previously reported, may be lithologically characterized as follow: 
WELL №

\section{FIGURE 2}

FORAMINIFERA

\begin{tabular}{|c|c|c|c|c|c|c|c|c|c|c|c|}
\hline SPECIES DEPT (meter $)$ & 21.00 & 24.00 & 2570 & 27.20 & 2870 & 30.25 & 3330 & 3635 & 39.40 & 42.50 & 45.50 \\
\hline \multicolumn{12}{|c|}{ 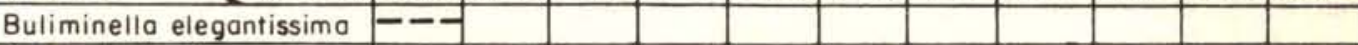 } \\
\hline Cyclogira involvens & -- & --- & & & & & & & & & \\
\hline Cassidulina crassa & -- & & & --- & & & & & & & \\
\hline Articulina s p & -- & & & & & --7 & & & & & \\
\hline Morulaeplecta narchii & --- & & & & & -- & --- & & & & \\
\hline Spirolocutina $s p$ & -- & & & & & & --- & & & & \\
\hline Cancris sagra & --- & --- & & & -- & --- & --- & & & & \\
\hline Iquapia limai & --- & --- & & & & & & & & & \\
\hline \multicolumn{12}{|l|}{ Spiroplectamina toddi } \\
\hline \multicolumn{12}{|l|}{ Globigerina bulloides } \\
\hline Siphouvigerina clossi & & --- & --- & & & & & & & & \\
\hline \multicolumn{12}{|l|}{ Hanzawaia concentrica } \\
\hline \multicolumn{12}{|l|}{ Quinqueloculina kollerti } \\
\hline \multicolumn{12}{|l|}{ Nonionella atlântica } \\
\hline \multicolumn{12}{|l|}{ Discorbis boltovskoyi } \\
\hline \multirow{2}{*}{\multicolumn{12}{|c|}{$\begin{array}{l}\text { Bulimina marginata } \\
\text { Brizalina striatuta }\end{array}$}} \\
\hline & & & & & & & & & & & \\
\hline \multicolumn{12}{|l|}{ Cribroelphidium poeyanum } \\
\hline \multicolumn{12}{|c|}{\begin{tabular}{|l|l|l|} 
Ammonia catesbyana & & \\
\end{tabular}} \\
\hline Globigerinoides quadrilobatus trilobus & -- & --- & --- & & & & & & & & \\
\hline Trifarina ocidentalis & -- & --- & --- & & & --- & & & & & \\
\hline Nonion s p. a & & -- & & & & & & & & & \\
\hline Fissurina s p.a & & --- & & $--\infty$ & & -7 & & & & & \\
\hline Fursenkoina $s p$. & & --- & --- & & --- & & & & & & \\
\hline Nonion s p b & & & --- & & & & & & & & \\
\hline Lagena sp a & & & --- & & --- & & --- & & & & \\
\hline Sigmoilina sp. & & & & --- & & & & & & & \\
\hline Cibicidoides sp. & & & & --- & & & & & & & \\
\hline Bucella campsi & & & & --- & & & & & & & \\
\hline Rosalina floridana & & & & & --- & --- & --- & & & & \\
\hline Planulina $s p$ & & & & & & -- & & & & & \\
\hline Dyocibicides bisserialis & & & & & & --- & & & & & \\
\hline Cibicides sp a & & & & & & --- & & & & & \\
\hline Cyclogira planorbis & & & & & & --- & --- & & & & \\
\hline Nodosaria catebyi & & & & & & --- & --- & & & & \\
\hline Globocossidulina subgloboso & & & & & & --- & --1 & & & & \\
\hline Oolina hexagona & & & & & & & --- & & & & \\
\hline \multicolumn{12}{|l|}{ Miliolinella circularis } \\
\hline Cibicides sp b & & & & & & & ---1 & & & & \\
\hline Cibicides SP C & & & & & & & -- & & & & \\
\hline Discorbis? & & & & & & & --1 & & & & \\
\hline Fissurina lucida & & & & & & & --7 & & & & \\
\hline Fissurina lagenoides & & & & & & & --- & & & & \\
\hline Fissurina sp b & & & & & & & --1 & & & & \\
\hline Fissuring sp.c & . & & & & & & --7 & & & & \\
\hline Lagena sp b & & & & & & & -1 & & & & \\
\hline \multicolumn{12}{|c|}{ DIATOMS } \\
\hline Polymixus coronalis & & --- & --- & --- & --- & --- & --- & & & & \\
\hline Terpsinoe musica & & --- & --- & --- & ---1 & --- & & & & & \\
\hline Triceratium patagonicum & & --- & --- & --- & $E--$ & --- & & & & & \\
\hline Triceratium favus & & -- & --- & --- & --- & --- & & & & & \\
\hline Coscinodiscus asteromphalus & & & & & & --- & & & & & \\
\hline Cyclatella striata & & & & & & & & & & & \\
\hline
\end{tabular}


Sequence I - Sands and conglomeratic sands with subordinate argillaceous layers. These deposits were probably laid down in a coastal plain environment. They constitute the base of the sedimentary sequences.

Sequence II - Fine sediments, silty clays with abundant diatoms and few forams; rest on the sequence I sediments. The diatoms are mostly fitted to brackish water environment and the forams belong to euryhaline and eurythermal species.

Sequence III - Sandy silts rest on the sequence II sediments. They were laid down in a marine environment as proved by the abundant well preserved forams.

Sequence IV - The sediments of the sequences I to III are relatively coherent, so it was possible to take cores from the wells. The sequence IV, on the other hand, is a fine and friable sand which however may be cemented by a ferruginous material acquiring certain con- sistence, then being locally called piçarra. But in the wells it is very difficult to obtain cores of this material. We propose, as stated previously, to call this lithological unity Cananéia Formation.

The four unities of sediments do not have the same development in the two wells as can be seen by the figure 1 (lithological profiles of the two wells). The whole thickness of the sediments is smaller in the well no 1 , however the marine sediments are thicker than in the well n. 2. The conglomerates and the conglomeratic sands of the sequence I are rather thick in the well $\mathrm{n} .2(118 \mathrm{~m}$, as a minimum, inasmuch the crystaline basement was not reached), and are not present in the well n? 1 .

The thicker marine section of the well $n$ ? 1 does not indicate however greater negativity in this area.

There is a paralelism between the two wells as can be seen by the lithological descrip-

\section{WELL N $N 2$}

\section{FIGURE 3}

FORAM IN I FE RA

\begin{tabular}{|c|c|c|c|c|c|c|c|c|c|c|}
\hline SPECIES DEPTH (meter) & 30.80 & 36.70 & 39.80 & 42.80 & 45.90 & 48.90 & 7025 & 8855 & 9160 & 161.00 \\
\hline Quinqueloculina s p. a. & --- & & & & & & & & & \\
\hline Quinqueloculina s p.b & ----1 & & & & & & & & & \\
\hline Lagena s p a & ---- & & & & & & & & & \\
\hline Bolivina pseudoplicafo & $-\rightarrow-1$ & & & & & & & & & \\
\hline Spiroloculina s p. & ---1 & & & & & & & & & \\
\hline Oolina s $p$ & ---1 & & & & & & & & & \\
\hline Fissurina lucida & ---1 & & & & & & & & & \\
\hline Cyclogiro involvens & ---- & ---1 & & & & & & & & \\
\hline Siphouvigerina clossi & --- & ---- & & & & & & & & \\
\hline Bulimina marginata & & ---1 & & & & & & & & \\
\hline Fursenkoina $s \mathrm{p}$. & & ----1 & & & & & & & & \\
\hline Trifarina acidentalis & & ---1 & & & & & & & & \\
\hline Quinqueloculina kollerti & & & & & & & & & & \\
\hline Brizalina striatula & & & & & & & & & & \\
\hline Hanzowaio concentrica & & & & & & & & & & \\
\hline Ammonia catesbyano & & & & & & & & & & \\
\hline Cribroelphidium poeyanum & & & & & & & & & & \\
\hline Discorbis boltovskoyi & & & & & & & 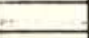 & & & \\
\hline Spiroplectammina toddi & & & & & & & & +1) & I & \\
\hline gugpia limai & & & & & & & & & & \\
\hline $\begin{array}{l}\text { Nenionelle aflentica } \\
\text { Globigerinoides quadrilobatus trilobus }\end{array}$ & & & & & & & & & & \\
\hline Milielinello circularis & & & & & & & & & & \\
\hline Rosaling fleridena & & ----1 & & & & & & & & \\
\hline- & & & & $D \perp A$ & $\mathrm{TOM}$ & S & & & & \\
\hline Polymixus Coronalis & ----1 & ---- & & & & & & & & \\
\hline Terpsinoe musica & ---- & ---- & & & & & & --- & --- & ---- \\
\hline Triceratium patagonicum & --- & ---- & & & & & & & $--\infty$ & \\
\hline Triceratium favus & ---1 & ---- & & & & - & & & $-\infty--$ & \\
\hline Coscinodiscus asteromphalus & & & & & & ---1 & & & & \\
\hline Cyclatella striata & & & & & --- & ---1 & & & & \\
\hline
\end{tabular}


WELL I.G.G. NNI- - DEPTH IN METERS

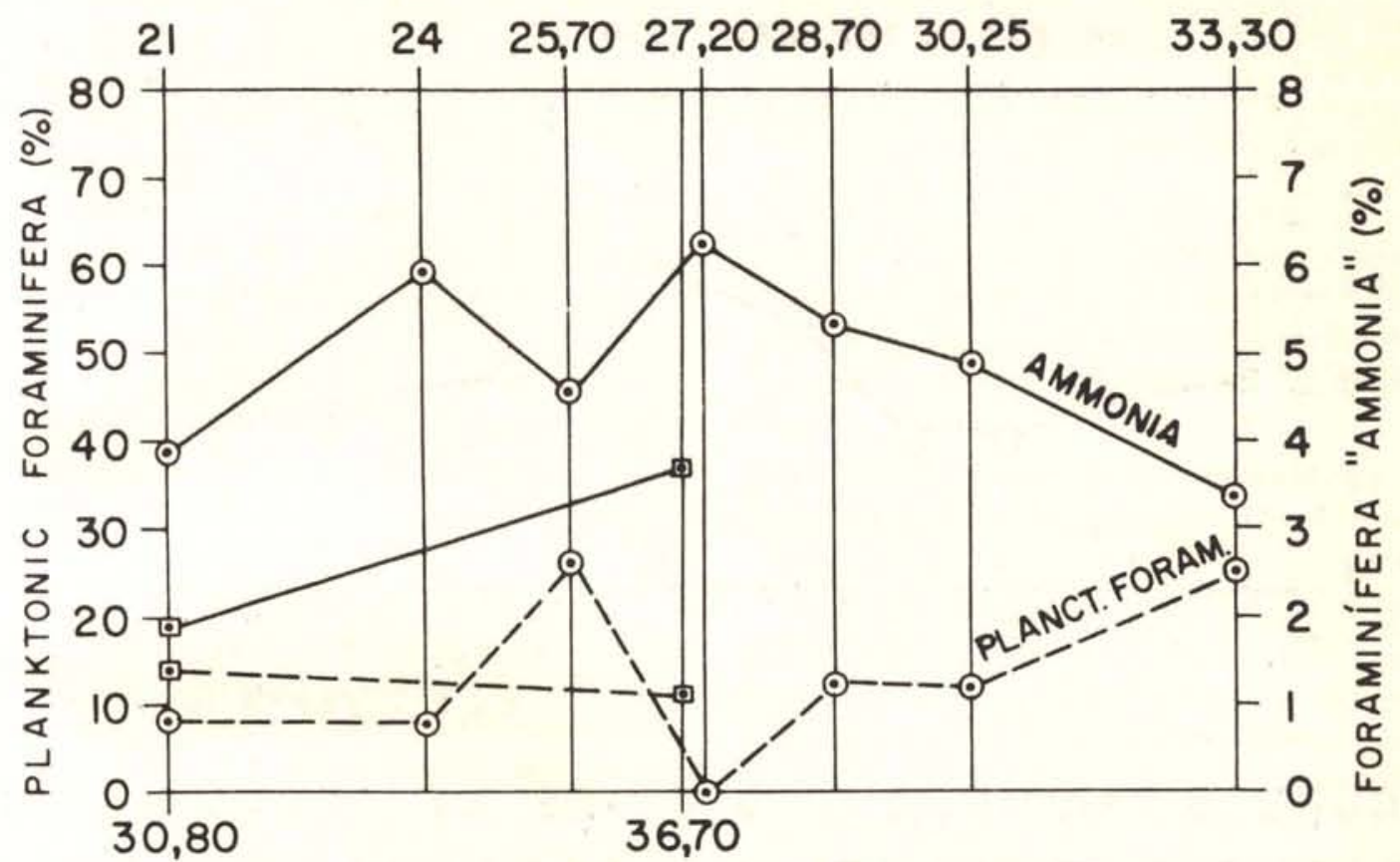

WELL I.G.G. NN2-DEPT IN METERS

\section{FIGURE 4 -PERCENTAGE FREQUENCIES OF "AMMONIA" AND OF PLANKTONIC FORAMINIFERA AS A FUNCTION OF DEPTH IN THE WELLS DRILLED BY I.G.G.}

tions of the drilled sediments down to $47 \mathrm{~m}$ in the well no 2. From these depth however, while the crystaline basement was reached in the well n. 1 , the basal sequence I was reached in the well n. 2, formed by $118 \mathrm{~m}$ of non-marine mainly coarse sediments. We believe these sediments were laid down in a strong subsidence area, adjacent to areas in elevation resulting in a high rate of sedimentation and preventing in this way the advance of the sea. As a consequence of the high speed of sedimentation unstable minerals were preserved, such as biotite with its original color and also unweathered feldspars.

Later, when the rate of erosion declined, associated with a slight increase in the subsidence rate the conditions changed to a quieter one and the sediments of the sequence II, still nonmarine, were deposited. The subsidence rate (or eustatic change) kept increasing and then the sea encroached upon the land and the marine section started to be deposited (sequence III).

The total thickness of sediments constituting sequences I to III were laid down during a transgressive phase, whereas the sediments from the upper half of the sequence III to the top of the sequence IV were sedimented in a regressive phase.

The last phase of deposition still in activity, recorded by the sequence $\mathrm{V}$, represents the progressive establishment of present conditions of sedimentation up to now, where there is a pattern of extensive bands of low sandy terraces of marine origin alternated by parallel lagoons of salty and brackish waters (BESNARD and AB'SẢBER, 1953, p. 215). Aeolian sands, as dunes, occur also in the Comprida Island. According to SILVEIRA (1952, p. 127) the whole Comprida Island, the Cana- 


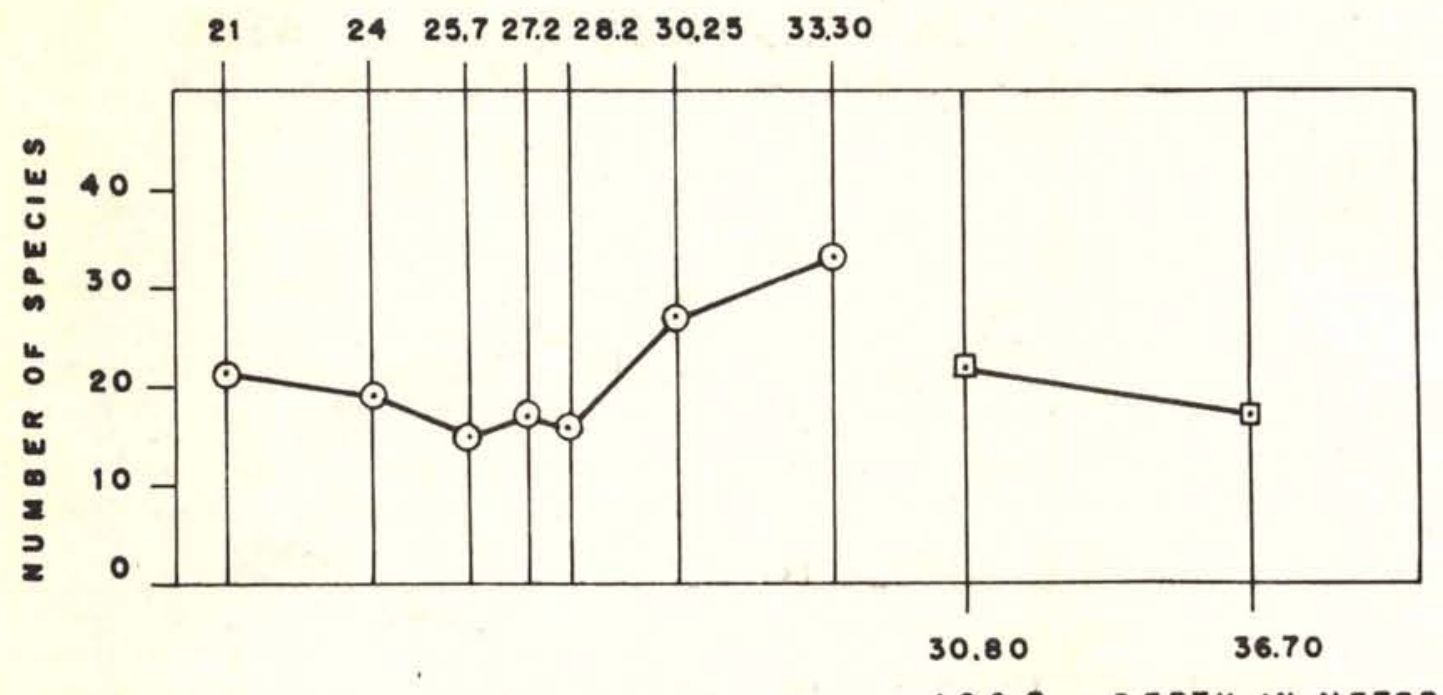

I.6.6. 2 - DEPTH IN METER

\section{FIGURE 5 - NUMBER OF SPECIES OF FORAMINIFERA AS A FUNCTION OF THE DEPTH IN THE WELLS.}

néia Island and even the Cubatão lowland near the Cubatão sea are beach ridge plains, making up a band of 5 or $6 \mathrm{~km}$ wide. In the chapter on regional geology (Part I of this work) we discussed in more details the present deposits.

The cemented sands called piçarra is responsible for the existence of small cliffs in the southwestern part of Comprida Island and at the other side of Cananéia and Pequeno seas in the Cananeia Island and the continent. According to SETZER (1949, p. 181) there are remnants of a fossil soil above the piçarra and above the fossil soil lay out the present dunes. BIGARELLA (1954, p. 235) stated that the picarra banks show typical beach structures, with strike and dip of the stratifications often fitting to the present beaches deposition.

The regressive phase of the Quaternary sea that left the geological record of the sequence IV sedimented was recognized by previous authors. KRONE $(1914$, p. 31) studying the distribution of shell mounds (sambaquis, in portuguese lenguage), made by the indians in the region, admitted that in those indians time the sea encroached upon the low
Ribeira Valley as far as $40 \mathrm{~km}$ from the present strandline forming a gulf. Northeastward and southwestward the gulf would approach the present strandline and in the area of Cananéia it would be only few kilometers wide. This would gradually restrict to the present situation.

BESNARD and AB'SÁBER (1953. p. 220) didn't accept KRONE's gulf but admitted for the lagoonal region, during the shell mounds indians time, a system of lagoons and marine sounds somewhat larger than the present one. These authors agree in one point: There was a time when part of the lagoonal area was covered by the sea. KRONE places the time of maximum transgression in the beginning of the Pleistocene; BESNARD and AB'SÁBER cautiously dated it from several centuries to several tens of centuries ago.

A positive epeirogenetic phase after the sedimentary filling up of the area reached by the sea is suggested by AB'SÁBER's interpretation (1955, p. 23) of the piçarra. They would represent uplifted beach and beach ridge sands slightly cemented becoming in this way resistent to erosion. 
The profiles of the I.G.G. wells (figure 1) show that the sea lasted more time in the Iguape area (well n! 1) than in the area near Cananéia (well $n ! 2$ ). The present fluvial drainage tend to converge to the Iguape area and this might be a legacy from that age.

The Pariquera Açu fluvial deposits (SILVEIRA, 1952 ; RICH, 1953; ALMEIDA,1964; BIGARELLA and MOUSINHO, 1965 and FRANZINELLI, 1970) must represent the phase of sedimentary filling up of the valleys of the rivers that flowed toward the Iguape-Cananéia lagoonal region, originally very wider. They would be a facies chronologically correlated with the sequences II and III, brackish and marine facies of the studied region. BIGARELLA and MOUSINHO (1965; p. 17) consider the Pariquera Açu Formations as Pleistocenic. If the sediments of this formation were laid down in a time when the sea-level was higher than now, therefore with a higher base level, which facilitate the sedimentation then a Holocenic age (post Pleistocenic glaciation) would be more probable (PETRI and SUGUIO, 1971a).

There is a depth in both wells, where consolidated beds below give way to unconsolidated beds above $(21 \mathrm{~m}$ in the well $\mathrm{n}$. 1 and $30 \mathrm{~m}$ in the well $\mathrm{n} \cdot \mathrm{2}^{2}$ ). This is true also in a well at Praia do Leste, State of Paraná, where consolidated sediments give way to unconsolidated sediments, $69.40 \mathrm{~m}$ deep (MAACK, 1949, p. 276). According to MAACK the upper sequence would be Holocene andt the lower, Pleistocene. There is nothing to prove this statement.

In short, the evidences yielded by the sediments from the two wells perforated by I.G.G. allowed us to deduce the following sequences of events: There was in the begining a time of relatively rapid subsidence, of tectonic origin, mainly in the area where now is the central part of the Comprida Island. The acceleration of the erosion prevent the ingress of the sea and the non-marine sequence I sediments were deposited. These sediments were found only in the well no 2. As the subsidence kept on acting, the sea encroached upon the land and the sequence II sediments, present in both wells, were laid down in brackish water environment firstly, followed by the marine sequence III sediments, also present in both wells. A still stand phase succeeded and the filling up of the area of marine transgression gradually drew back the sea, when the unconsolidated sequence IV sediments were deposited. A small scale positive epeirogeny occurred afterward and the picarra was uplifted. This uplift, however, was not enough to modify the predominantly lagoonal conditions still prevailing.

Eustatic movements of the sea level have possibly interfered with the tectonic movements.

If we assume that post-pleistocenic deglaciation, causing a rise in the sea level, was partially responsible for the marine transgression, then the sequence III sediments would be already Holocene in age and the sequence II would have been formed in the end of the Pleistocene. It is impossible at the present state of knowledge to have a more precise idea of these ages.

\section{FINAL CONSIDERATIONS}

The elements for the reconstruction of the geological history of the sedimentation processes at the Iguape-Cananéia lagoonal region were gathered from our field surveys, laboratory examinations of the samples and data published by previous authors.

The conclusions from our researches are:

a) An active sedimentation occurred in the Iguape-Cananéia coastal plain during the Quaternary period.

b) The sedimentation was a consequence of a typical marine transgression phase with a previous record of non-marine beds and the regression phase. The deposits probably are a direct result of the tectonism - epeirogeny eustatic changes interplay occurred during the Quaternary.

c) The geological instability of the studied area did not end with the closure of the sequence IV deposition here called Cananéia 
Formation. This formation was uplifted 5 to $6 \mathrm{~m}$ above sea level and the shore in this region is still uplifting as described by several authors and more recently by PETRI and FÚLFARO (1970) studiyng the Cardoso Island shore.

d) The depositional phase of the Cananéia Formation seems to have been very widespread extending northward to Praia Grande (near Santos City) through Itanhaem. Samples of sands from the beaches and banks in these regions have grain size frequencies cumulative curves essentially identical to those of the Cananéia Formation. Southward this formation extends to the State of Paraná.

e) Coarse continental sediments occur in the Ribeira de Iguape hydrographic basin, up from the lagoonal region as a reflex of the events occurred down river. They must be chronologically correlated with the phase of higher sea level causing the elevation of the base level. These coarse sediments are known as Pariquera Açu Formation. They are more frequent in the Jacupiranga River valley than in the Ribeira de Iguape valley, perhaps because they have been more exposed to erosion in the Ribeira valley (Jacupiranga river is a tributary of the Ribeira river).

f) The Government of the State of São Paulo is considering the possibility of building a harbor in this region for the anchorage of big ships. One of the serious handicaps for the development of the project is the great instability of the bottom sediments, principally at the Cananéia outlet * Sandy deposits formed as spits and tombolos are built and destroyed and at the same time bars move actively on the submarine bottoms (SADOWSKY, 1954; PETRI and SUGUIO, 1971b). Another serious problem is the erosion and the filling up at the town of Iguape. The damages cuased by sedimentation and resedimentation in this region are so great that if new informations put forward here, about the dynamics of sedimentation in the area, will be of some value for the resolution of the problems of the region, the authors will feel fully rewarded.

\footnotetext{
- A laboratory model of this has been very intensively studied, for many years, in the Instituto de Hidraulica of the Departamento de Águas e Energia Elétrica - University of São Paulo.
}

\section{BIBLIOGRAPHY}

AB'SẢBER, A.N. (1955) - “Contribuição à geomorfologia do litoral paulista" Revista Bras. de Geografia, n? 1, Ano XVII.

ALMEIDA, F.F.M. de (1964) - “Geologia do Estado de São Paulo; II - Fundamentos geológicos do relevo paulista Provincia costeira" - Bol. do I.G.G., n. 41, 226 p., São Paulo.

BESNARD, W. (1950) - "Considerações gerais em torno da região lagunar CananéiaIguape" - Bol. Paul. de Oceanografia, tomo I, fasc. 1, p. 9-26 e tomo I, fasc. 2, p. 3-28, São Paulo.

BESNARD, W. and AB'SÁBER, A.N. (1953) "Sambaquis da regiäo lagunar de Cananéia, São Paulo" - Bol. do Instituto Oceanográfico da Univ. de São Paulo, tomo IV, fasc. 1-2, p. 215-238, São Paulo.
BIGARELLA, J.J. (1954) - “Nota sobre os depósitos arenosos recentes do litoral sul brasileiro" - Bol. Instituto Oceanográfico da Univ. de São Paulo, tomo V, fasc. 1 e 2, p. 233-238, São Paulo.

BIGARELLA, J.J. and MOUSINHO, M.R. (1965) - "Contribuição ao estudo da Formação Pariquera-Açu, Estado de São Paulo" - Bol. Paranaense de Geografia, n. 16-17, p. 17-41, Curitiba. Paraná.

CLOSS, D. (1962) - "Foraminiferos e tecamebas na Lagoa dos Patos (Rio Grande do Sul)" - Bol. n? 11, Escola de Geologia da Univ. Fed. do Rio Grande do Sul, 130 p., Porto Alegre.

FRANZINELLI, E. (1970) - "Estudo sedimentológico da Formação Pariquera-Açu (Estado de São Paulo)" - M. Sc. Thesis presented to Instituto de Geociências e 
Astronomia of the Univ. of São Paulo, São Paulo (Unpublished).

KRONE, R. (1914) - "Informações ethno gráphicas do Valle do rio Ribeira de Iguape" - Comissão Geogr. e Geol., Estado de São Paulo.

LOEBLICH, A.R. Jr. and TAPPAN, H. (1953) - "Studies of Arctic Foraminifera" Smithsonian Mus. Coll., vol. 117, no 7, $150 \mathrm{p}$.

MAACK, R. (1949) - "Espessura e seqüência dos sedimentos quaternários no litoral do Estado do Paraná" - Separata, Arq. de Biologia e Tecnologia, vol. IV, art. 19, p. 271-286, Curitiba, Paraná.

MAGLIOCCA, A. and KUTNER, A.S. (1964) - "Conteúdo orgânico dos sedimentos do fundo de Cananeia, São Paulo"Instituto Oceanográfico, Contribuições Avulsas, Oceanografia Física n? 7, 13 p., São Paulo.

MILLER, D.N (1953) - "Ecological study of the foraminifera of Mason inlet, North Carolina" - Cushman Foundation Foram. Res., Contr. vol. 4, pt. 2, p. 41-63.

PETRI, S. and FÚLFARO, V.J. (1970) "Nota sobre a geologia e terraços marinhos da Ilha do Cardoso, SP" - Not. Geomorf., vol. 10, no 20, p. 21-31, Campinas, São Paulo.

PETRI, S. and SUGUIO, K. (1969) - "Sobre os metassedimentos do Grupo Açungui do Extremo Sul do Estado de São Paulo" - Covenant between "Departamento de Águas e Energia Elétrica (Serviço do Vale do Ribeira)" and the Univ. of São Paulo. Published by the "Secretaria dos Serviços e Obras Públicas do Estado de São Paulo", 98 p., São Paulo.

PETRI, S. and SUGUIO, K. (1971a)- "Some aspects of the Neo-cenozoic sedimenta. tion in the Cananeia-Iguape lagoonal region, São Paulo, Brazil" - Estudos Sedimentológicos, vol. 1. n. 91 , p. $25-33$, Natal, Rio Grande do Norte.

PETRI, S. e SUGUIO, K. (1971b) - "Un exemple de l'action de la mer sur le littoral du sud du Brésil" - Photo-interprétation, Éditions Technip, Paris.

PHLEGER, F. B. (1954) - "Ecology of foraminifera and associated microorganisms from Mississipi Sound and Environs" Amer. Assoc. Petrol. Geol. Bull. vol. 38, n. 4 , p. $584-647$.

RICH, J.L. (1954) - "Problems in Brazilian Geology and Geomorphology suggested by reconnaissance in summer of 1951" Bol. Fac. Filo. Ciênc. Letras Univ. de São Paulo, no 146, Geol. no 9, 80 p., São Paulo.

SADOWSKY, V. (1954) - "Novas contribuif̧ões ao estudo da entrada da Barra de Cananéia" - Bol. do Instituto Oceanográfico da Univ. de São Paulo, vol. 5, no 1-2, p. 151-176, São Paulo.

SETZER, J. (1949) - “ Os solos de Estado de São Paulo" - Biblioteca Gengráfica Brasileira, Publ. 6 da Série A "Livros", XIV, 388 p., Conselho Nacional de Geografia, Rio de Janeiro.

SUGUIO, K. (1969) - “Contribuição à geologia da Bacia de Taubaté, Vale do Paraiba, Estado de São Paulo" - Bol. Fac. Filo. Ciên. Letras da Univ. de São Paulo, bol. número especial, 106 p., São Paulo.

SUGUIO, K. and PETRI, S. (1973) - "Stratigraphy of the Iguape-Cananéia Lagoonal region sedimentary deposits. São Paulo State, Brazil" - Part I: Field abservations and grain size analysis" Bol. IG, Instituto de Geociências, USP, 4:1-20, São Paulo.

TEIXEIRA, C. and KUTNER, M.B. (1961) "Contribuição para o conhecimento das diatomáceas da Região de Cananéia" Bol. do Instituto Oceanográfico da Univ. de São Paulo, Tomo XI, fasc. 3, p. 41-76, São Paulo.

WALTON, W.R. (1964) - "Recent foraminiferal ecology and paeloecology" - in Imbrie J. and Newell, N., "Approaches to Paleoecology", p. 151-237 